\title{
12. Beyond the glass ceiling: The material culture of women's political leadership
}

\author{
Libby Stewart ${ }^{1}$
}

In October 1992 a female federal Australian senator made headlines after she displayed a poster that depicted a woman with a smoking gun over the caption 'so many men, so few bullets' in her Parliament House office window. In one newspaper article, titled 'Make My Day', it was reported that Parliament House authorities had received complaints that the poster in question was offensive, and asked for it to be removed. ${ }^{2}$ The senator in question, Jocelyn Newman, was a senior parliamentarian from the conservative side of politics who was making a strong statement in favour of women's representation in an overwhelmingly male-dominated parliament, and she refused to take the poster down.

Senator Newman was at one point labelled the most powerful woman in Australian politics and a contender for Australia's first female governor-general. Yet during her period in politics she endured many stereotypical depictions of her gender, including her dress sense and her role as a wife and mother-portrayals that attempted to undermine her authority as a successful female politician. She was not alone in being trivialised in this way; indeed the gendered depictions of Australian women in politics continue to the present. Julia Gillard, Australia's first female prime minister, also endured taunts from her opposition colleagues and the public relating to her status as an unmarried, childless woman in power. An empty fruit bowl in her kitchen that she was photographed in front of in 2005 was singled out as 'evidence' of her lack of authority to hold senior office. To some people the bowl was a symbol of her lack of domestic skills, a sign that she was unqualified for office because she was childless and apparently careerdriven, that she lacked empathy, and even that she was 'deliberately barren'. ${ }^{3}$

Objects such as Senator Newman's 'smoking gun' poster and the Gillard fruit bowl can be powerful tools for museums to use in telling the stories of women leaders in politics. This chapter looks at some of the collections of the material culture of women's political leadership that are held by the Museum of Australian Democracy (MoAD) at Old Parliament House in Canberra. Objects

\footnotetext{
1 The Museum of Australian Democracy at Old Parliament House.

2 'Make My Day', Sun Herald, 4 October 1992.

3 The 'deliberately barren' statement was made by Queensland Liberal Senator Bill Heffernan in 2007. He was later forced to apologise for the slur.
} 
such as those described above, when displayed in context, showcase the many diverse aspects of women's political activism and political lives. Women who have been successful in achieving political office, as well as women who have been political activists, all have stories that museums can tell through the display of objects like awards, photos, political campaign material, jewellery, clothing, papers and posters. The suffragists of the early twentieth century were some of the first successful users of objects to promote their cause and MoAD has a small collection of these, which it displays as powerful reminders of women's struggle for the vote, both in Australia and in Britain. But the museum also holds collections of more mundane items. Seemingly insignificant, these objects, viewed in context, enable the museum to tell meaningful and important stories of the lives and political actions of Australian women leaders. They also enable the museum to discuss women's different leadership styles-evident in the kinds of objects used to tell each woman's story. Through an examination of a number of the museum's collections it is possible to see how important it is that museum historians and curators search widely and with open minds for collections of objects that tell stories as fascinating as those to be found in collections of documents held in libraries and archives.

The mundane and apparently insignificant nature of some of MoAD's collections that have belonged to Australia's female leaders would appear, at first glance, to reflect some of the ambivalence about the notion of leadership itself. Typical of the mixed feelings about the nature of women's leadership is a comment made several years ago by Pat Giles, the inaugural chair of the Women's Electoral Lobby of Western Australia, and a federal senator for that State for more than 10 years. She said: 'My forte, I think, has been as a facilitator rather than a leader. Leadership has been far from my mind, and even now seems alien, a masculine construct which bears little resemblance to what I have been doing for the last 25 years.' $^{4}$

In her opening chapter of this book, Amanda Sinclair also recognises the feminist ambivalence towards leadership, noting that 'leadership as the lionisation of the achievement of individuals in powerful privileged positions is the antithesis of what many women have fought for' ${ }^{5}$ Women like Giles, who have been politically active and have achieved a great deal as leaders, have often received items such as certificates of appreciation, awards, gifts and plaques in the course of their work. These objects are sometimes dismissed by the recipients as unimportant, perhaps because the women feel ambivalent about the notion of leadership and attribute their success to being part of a wider team or to simply doing their job.

4 Quoted in Joan Eveline and Lorraine Hayden, eds, Carrying the Banner: Women, Leadership and Activism in Australia (Perth: University of Western Australia Press, 1999), 43.

5 Amanda Sinclair, Chapter 1, in this volume. 
There is a strong case, however, for arguing that these objects should be regarded as valuable tools that can enable museums to better tell the stories of these women's leadership journeys. Too many stories of remarkable women in Australia and elsewhere have been lost because papers, photos or objects no longer exist to mark their place in history. An example of this loss lies in the stories of four remarkable Australian women: Vida Goldstein, Nellie Martel, Mary Ann Moore Bentley and Selina Anderson. They were the first women to stand for federal election in 1903 - the first occasion at which women were eligible to do so. None was successful, and although the efforts of Vida Goldstein to be elected to Federal Parliament a further four times are well documented in writing, photos and film, the later lives of the other three women, who were without doubt female leaders of their time, are largely unknown to most Australians. This is a great shame because all three were dynamic and courageous: on a platform of equal wages for women and promoting domestic issues, Martel gained a respectable 18,500 votes in 1903, while Moore Bentley was already a writer (having published $A$ Woman of Mars; or, Australia's Enfranchised Woman in 1901) and gained nearly 19,000 votes in her bid for the Senate, and Anderson stood for election as an independent protectionist, polling a respectable 18 per cent of the vote. Their stories deserve to be known more widely but any museum would struggle to do so without items of material culture relating to their lives.

Many Australian libraries and museums do hold wonderful collections of material relating to the lives of women, and many also feature regular exhibitions that tell the stories of some of them. It has not been standard practice in Australia, however, to build museums or develop permanent displays devoted to women's lives, as is the practice in many other parts of the world. Only three Australian museums - the Pioneer Women's Hut in Tumbarumba, NSW, the Pioneer Women's Memorial Folk Museum, near Brisbane, and the National Pioneer Women's Hall of Fame in Alice Springs - are wholly devoted to telling the stories of women's personal and professional lives. Of the three, the last has the broadest brief to look at the lives of a wide spectrum of women, as it is 'dedicated to preserving the place of women in history for their special contribution to Australia's heritage' ${ }^{6}$ It also has the closest links to the approximately 40 other women's museums around the world and promotes the importance of women's museums in helping to raise women's status and self-esteem. ${ }^{7}$ This small museum in the heart of the country is, however, almost a lone voice amongst larger and betterfunded museums that at times marginalise or ignore women's stories.

6 National Pioneer Women's Hall of Fame, Alice Springs, NT, website: http://www.pioneerwomen.com.au/ index.php.

7 See website (http://www.pioneerwomen.com.au/index.php) for the National Pioneer Women's Hall of Fame's aims and links to international women's museums. 
The lack of women's representation in Australian museums has been recognised by industry professionals and in 1993 the National Museum of Australia in Canberra convened a conference on the subject 'Images of Women', to develop recommendations for how the portrayal of women's lives in the public sphere could be improved. In her keynote address at that conference, actor and arts patron Robyn Archer called on Australian museum professionals to try to 'ensure that in the future no less than half of the picture is devoted to what women have done with their time on earth, what they have achieved, what they have endured'. She wanted women's often silent and invisible role in creating the present to be fully acknowledged and respected because, she said, 'due respect for women now ... will only come with the sure recognition that we were always there in all sections of society and that without our extraordinary strength there is no real past, no present and no future' ${ }^{8}$

One of the conference workshops devoted to looking at women's leadership journeys recommended that museums should enable all women to value their achievements as well as demonstrating the achievements of those who have reached 'the top'. But it also recommended that the definition of 'the top' should include the capacity to contribute to decision-making and effect change. Not only should traditional leadership models be recognised, so too should hidden stories of strength and achievement as they demonstrate a different kind of women's leadership. ${ }^{9}$ Nearly 20 years after those recommendations were made, it is, however, apparent that there is still much to be done to improve the representation of women's leadership in Australian museums, libraries, archives and galleries.

What are the kinds of collections that museums can use to tell meaningful stories of women's political lives and leadership? One of the stories of women's political activism already told by MoAD is that of women's suffrage in Australia. The museum discusses the close links between Australian suffragists and their counterparts in countries such as Britain and the United States, where it took much longer for women to achieve the vote. Objects relating to the campaign for women's suffrage in the United Kingdom are visually arresting, and they easily convey the determination and strength of the women who led the campaign through its most militant stages. British suffragists, and in particular the militant suffragettes, became adept at designing and merchandising a wide range of goods to promote their cause and raise funds. MoAD has purchased a number of these objects in order to create a collection that can convey both the British struggle for the female vote and the close connections with Australian suffragists in its exhibitions.

8 National Museum of Australia, Images of Women: Women and Museums in Australia (Canberra: National Museum of Australia, 1994), 26.

9 Ibid., 90-1. 
One such item purchased by the museum is a women's suffrage pendant, which is typical of the type of jewellery worn by many women to indicate their support for the suffrage movement in Britain from the early part of the twentieth century. The inscription on the rear of the pendant, VFW 1905, suggests that it was associated with support for the militant British suffragette 'Votes for Women' campaign, which was launched in Manchester in 1905. The colours of the stones in the pendant are those of the constitutional suffragists, adherents of the National Union of Women's Suffrage Societies, who used red and white from as early as 1906 and added green in 1909.

Another women's suffrage group, the militant Women's Social and Political Union (WSPU), also adopted a colour scheme, using purple, white and green in all of its merchandise from 1908 onwards. The formation of the WSPU in 1903 marked a break from the politics of demure persuasion in the earlier period of the suffrage campaign. Frustrated at the lack of progress from years of moderate speeches and promises about women's suffrage from members of parliament, WSPU founder Emmeline Pankhurst and her colleagues decided the only way forward was to abandon these patient tactics in favour of more militant ones. The WSPU opened shops throughout London and in major cities and towns throughout England, selling a wide range of merchandise in their distinctive colours, to raise money and to advertise their cause. One of the most eyecatching, the board game Pank-a-Squith, was sold from 1909 onwards. Named after Emmeline Pankhurst and prime minister Herbert Asquith, an opponent of women's suffrage, the game is a powerful reminder of the hardships endured by many women as they committed acts of violence, were sent to prison and were often force-fed, in their efforts to obtain votes for women.

One British suffragette sent to prison for her part in a window-smashing raid was fifty-six-year-old Charlotte Blacklock. In March 1912, Charlotte turned from passive protest to militancy and was one of dozens of women arrested for using hammers to smash the windows of shops in Piccadilly, Haymarket, Oxford and Bond streets. The incident was widely reported and the damage to property was defended by Emmeline Pankhurst's daughter, Christabel, who said:

It is a protest against the Government's refusal to legislate in regard to the question of woman suffrage ... We are persuaded that the Government will not do anything until they are forced. As they do not yield to the justice of our demand we have been practically forced into adopting these tactics. ${ }^{10}$

Although the event took place in London, so many women were arrested that Charlotte was one of a number of women sent to jail in Birmingham. Like many

10 The Times, 2 March 1912. 
women arrested after a violent demonstration, Charlotte, once sent to prison, went on hunger strike and was force-fed - a brutal and dangerous process that often left women either permanently scarred or fatally injured. Released after her four months' sentence, Charlotte was awarded a hunger strike medal, one of only about 100 produced by the WSPU to recognise the bravery of women who went without food and suffered from being forcibly fed.

The medals were intended to be the suffragists' equivalent of the highest imperial award for bravery under fire, the Victoria Cross (VC). Like the VC, the hunger strike medals featured the words 'For Valour', as well as a metal bar engraved with the dates on which the recipient was arrested. Many of the medals, such as that given to Emmeline Pankhurst, feature a number of bars - a testimony to the women's courage and persistence. Like the others, Charlotte Blacklock's medal features a ribbon in the suffragette colours of purple, white and green, and was purchased by MoAD in 2011; it is one of only three known to be in Australian public collections. A powerful object despite its simplicity, it serves as a graphic reminder of the lengths to which women would go in order to obtain the vote.

Although the museum now has a small but important collection of objects portraying the activism of British suffragists, it has been more difficult to find items that tell the Australian story of women's suffrage. The reasons for this are varied but include the fact that they are fewer in number, many are already held in both private and public collections, and Australian women acquired the vote relatively peacefully. Women in the colony of South Australia became the second in the world (after New Zealand) to be given the vote, and the first to be granted the right to stand for election. Both of these gains took place simultaneously in 1894 .

One item the museum has obtained is a rare pamphlet, produced in 1907 by the National Union of Women's Suffrage Societies, which highlights the way in which the early gains by women in New Zealand and Australia were used by British women in support of their claims for suffrage. Keen to reassure men that giving women the vote would not impact negatively on their lives, the AgentGeneral for South Australia, Sir John Cockburn, is quoted in the pamphlet as saying that 'women sedulously exercise their voting power without neglecting a jot of their domestic duties ... this great reform has been all gain without one single drawback'. ${ }^{11}$ The Agent-General for Western Australia, which granted women the vote in 1899, noted the positive effects of the female vote in the 1904 general election: 'The most gratifying features of the whole elections were the close interest exhibited by the women throughout the contest on polling day, and the general recognition by the community that the results justified the change

11 National Union of Women's Suffrage Societies, Women's Suffrage in New Zealand \& Australia (London, 1907), 3. 
made.' ${ }^{12}$ Another rare item, a suffrage demonstration program from 1910, makes particular mention of the fact that women from around the world, including Australia, were expected to march in the London event, to be held on 23 July. It also contains illustrations of a number of prominent suffragettes, including Adela Pankhurst, who later settled in Australia and became a prominent activist for women's rights.

Although the MoAD places great importance on portraying the history of women's suffrage, its curators and historians are also keen to shed light on the lives of many other women active in the political sphere. In recent years they have collected items from two prominent female Australian politicians: senators Dorothy Tangney and Jocelyn Newman. Both women worked in the building in which the museum is now housed, Old Parliament House. They took leadership roles in their political lives and their collections reflect the complexity and diversity of those roles, as well as the way they were publicly perceived. Dorothy Tangney was a trailblazer, the Australian Labor Party Senator for Western Australia and in 1943 the first woman to be elected to the Senate, some 41 years after women won the right to stand for federal election. Until 1999 she was the longest-serving woman member in an Australian parliament, with a service record of 29 years and nine months. Many of the items in the Tangney collection show a clear leadership path: she received the Secondary School Scholarship Medal in 1919, the Junior University Medal and the Leaving University Medal, in 1920 and 1923 respectively, a Debating Medal in 1933, a Senator's Gold Pass, Jubilee and Coronation medals, a Gold Life Pass (issued to former parliamentarians for rail travel), and finally was made Dame Commander of the Order of the British Empire on her retirement in 1968. These items clearly reflect Dorothy Tangney's abilities, as well as the determination with which she approached her whole career - one she devoted to the causes of health, welfare and women's rights. A woman of both charm and quick wit, she was renowned for stories such as the time she was supposedly accosted by a drunk at a meeting, shouting 'don't you wish you were a man?', and the audience applauding her quick retort: 'No-don't you?'13

Although a strong and determined woman, Tangney enjoyed feminine touches in her Parliament House office and always took a tablecloth with her everywhere she went. One of these tablecloths is now held in the museum's collection. But Tangney also had room in her office for something slightly more unorthodoxan object that says much about her position as one of only a handful of women in the Australian Parliament of the 1940s. In December 1944, Tangney officiated at her first boat launching when she travelled to Maryborough, Queensland,

\footnotetext{
12 Ibid.

13 'Dorothy Tangney, Senator 1943-68', Australian Women's History Forum, http://www.womenshistory. com.au/image.asp?iID=333.
} 
to launch the navy frigate HMAS Shoalhaven. Having smashed the obligatory bottle of champagne against the vessel, she watched as the ship moved slowly down the slipway and into the sea. In line with tradition, Tangney received the remains of the bottle as a souvenir of the day; however, in this case the shipbuilder attached the bottle head to a wooden handle, creating a crude type of axe. Dorothy kept the axe for the rest of her life, displaying it with some pride in her office with the note from the shipbuilders that read: 'To Senator Dorothy Tangney. To be used as and when required.'

Most of the other items in the Tangney collection are not as remarkable or quirky as the champagne bottle axe, however, they convey a sense of the life and personality of the owner equally well. There is a hand-drawn nameplate, a suitcase, a small souvenir purse from Rome, a luggage label from a trip on the Queen Mary from New York to London, an election advertising card, and a wishing well given as a gift. With this collection, the museum is able to convey something of the nature of Dorothy Tangney herself, her life as a politician in this house and her life more generally, from her early years to her retirement. Through these objects, the working life of one of the country's trailblazing female politicians will be remembered by many generations of visitors to the museum.

Former senator Jocelyn Newman has donated to the museum a large collection of objects relating to both her own working life and that of her husband, former MP Kevin Newman. Jocelyn Newman began her parliamentary career in 1986 when she was elected a senator for Tasmania. She held the portfolio of defence in opposition, then was appointed Minister for Social Security following the election of the Howard Coalition Government in 1996. In 1998 she was moved to the portfolio of Family and Community Services, and on two occasions held the position of Minister Assisting the Prime Minister for the Status of Women. Described by the Melbourne Herald at one stage as both a superwoman and 'the liberated Lib', ${ }^{14}$ Newman was, amongst other things, committed to equal education opportunities and equal pay for women.

Unlike Tangney's collection, the objects donated by Jocelyn Newman do not reflect a clear leadership path to the political heights that she eventually reached. Rather, Newman's collection reflects the variety of her life experience, as well as the solid partnership she had with her husband, Kevin. In her early married life with Kevin, who was a career soldier, Jocelyn frequently moved her young family between posts. She also spent a long year without Kevin when he served a tour of duty in Vietnam. As an army wife, she later commented, 'we had to develop the ability to get out and meet people and to make wherever we

14 Herald [Melbourne], 14 June 1975. 
were feel like home' ${ }^{15}$ These were undoubtedly useful qualities for a later life in politics. As well as raising two children, Newman studied law, practising as a barrister and solicitor, and then settled in Launceston when Kevin successfully contested the Bass by-election in June 1975. In Launceston, Jocelyn effectively had a crash course in holding a marginal seat:

We had a marginal seat so I was just sort of the underling to the local member. I was keeping the family name and the involvement in Bass in front of everybody so that anything that needed to be done or anywhere that needed a speech, I'd go and give it because he would have to be away somewhere. ${ }^{16}$

When a Senate vacancy occurred in 1986, Newman applied for preselection, not really believing she had a chance of winning. This was despite her solid experience: as well as the roles already mentioned, she played a central part in establishing the first women's refuges in Hobart and Launceston, had been prominent in the National Trust and had helped to run a guesthouse. Her credentials must have been regarded as significant because Jocelyn won the seat over a former State president of the Tasmanian Liberal Party, and another man, who had headed the Tasmanian Farmers and Graziers Association.

The items held in the museum's Newman collection, although not remarkable individually, need to be viewed as a whole because together they reflect some of the political achievements Jocelyn Newman was obviously proud of, as well as some of the particular pressures she faced as a woman in federal politics, and the particular leadership style she adopted. A set of her speech notes from 2000 reflects her longstanding interest in women's issues: she covered the topics of women's role in the economy, various aspects of women's paid and unpaid work and women's superannuation, women's health - in particular, breast cancer and the need for access to the most up-to-date contraceptive pills, and the problems associated with domestic violence against women. Another of her items, a framed photo of the women in federal politics in the 1990s, suggests a certain pride in the achievements of Australia's female MPs. Newman mentored younger Liberal women over many years and one of those who benefited, Helen Coonan, said Newman 'was someone who took the role of a friendly face, a kind word and a mentoring approach very seriously. If you don't have any of those it's like you've landed on the moon when you get to Parliament. ${ }^{17}$ Like Tangney, Newman also launched a ship, the Australian Customs Vessel Storm Bay, in Hobart in 2000, and she kept a framed memento of that event.

15 Ibid.

16 Margaret Fitzherbert, So Many Firsts: Liberal Women from Enid Lyons to the Turnbull Era (Sydney: The Federation Press, 2009), 135.

17 Ibid., 164. 
From time to time media attention would focus on Newman specifically as a female politician. In a 1996 cartoon, published in the Hobart Mercury, she was shown with a rack of aprons behind her, standing in front of a mirror trying another apron for size and thinking, 'Dear oh Dear ... (sigh) ... A woman's work is never done!' The caption below says, 'Jocelyn ponders what to wear ... As another tough day at the office looms.' ${ }^{18}$ That she kept a framed copy of the cartoon possibly indicates Senator Newman had a sense of humour about such a portrayal. Perhaps, though, she regarded two newspaper headlines from 1998 and 2000 with more pride. She kept both as framed, full-sized newspaper banners; the first reads 'Our Most Powerful Woman' and the second, 'Newman Tip for Gov-Gen' (governor-general). ${ }^{19}$

Several items in the Newman collection reflect the collaborative nature of Jocelyn and Kevin's marriage. There is a photo album with images showing Kevin at events around the country, often with Jocelyn at his side, as well as one of Jocelyn with young family members in T-shirts that show their support for Kevin at election time. Two portraits of the pair, by artist Audrey Wilson, are significant as a portrayal of one of the very few husband and wife teams in Australian federal politics. Although not of the highest quality as artworks, these paintings convey much of the personality and appearance of two highly successful and influential federal parliamentarians. Jocelyn relied heavily on her husband during two separate battles with cancer in the mid 1990s, and she was bereft when she lost Kevin to illness in 1999. It would be incorrect to depict successful women leaders as if they achieved everything on their own, and with the Newman collection the MoAD is able to tell a subtle but more realistic story of how one woman achieved success in her chosen field.

A few of the museum's smaller collections show how museums can display the diversity of women's leadership experiences through significant objects. In 1975 Parramatta City Council, in Sydney, was awarded an International Women's Year government grant to stage the exhibition 'Fifty Famous Australians'. The one female member of the council, Elizabeth Boesel, organised the exhibition, which consisted of photos and biographies of 50 women, present and past, who were regarded as having been influential in Australian political, social and cultural life. They included Louisa Lawson, Caroline Chisholm, Edith Lyons, Annabelle Rankin and Judith Wright. But the exhibition also had a local touch: two banners were handmade by local Parramatta women and they flew from the front of the Parramatta Post Office building where the exhibition was staged. Local women and girls were also given their voices in exhibition panels, which

18 Mercury [Hobart], 29 May 1996.

19 Examiner [Launceston], 9 November 1998; and Herald Sun, 17 October 2000. 
capture the spirit of the times during that significant year for women around the world. On one panel, a young local girl, Ceinwen, expressed her hopes for the future:

I want to be a ballerina; I want to be an architect, or even an engineer. I want to be so many things when I am grown up; I hope I can be the sort of person that I choose to be, because I am learning and doing and being many things. But the thing I like best is being Ceinwen. I am a very special person - a child of golden promise. ${ }^{20}$

Another item that evokes a particular period is a poster by artist Carol Porter, produced for the Victorian Women's Trust after the conservative Howard Government was elected in 1996. It depicts in bright pink words the slogan 'Don't get mad, get elected!' above a giant brunette woman, clad in a tight pink outfit and trainers. She towers over Parliament House in Canberra, while below her tiny suited men run screaming as she clutches one of their colleagues upside down. Porter commented that the poster tapped into a feeling, which was particularly strong at the time, that women should get into power and make a difference, ${ }^{21}$ and it followed a move by the Australian Labor Party, which in 1994 had adopted an affirmative action quota in order to get more women into federal politics. The poster was mounted on billboards at prominent intersections around Melbourne, proving to be extremely popular amongst the general community, and generated significant media interest in the issue. ${ }^{22}$

In 2010 the museum received a significant object from the country's first female governor-general, Her Excellency Ms Quentin Bryce AC. Bryce donated a fabric corsage, handed down to her by her mother but originally owned by her grandmother. The corsage is made up of tiny flowers in the suffragette colours of purple, white and green, and was worn by Bryce on significant occasions, such as the swearing in of Julia Gillard as the nation's first female prime minister in 2010. The corsage is highly significant for the museum because it links the views of two generations of feminist women-Bryce and her grandmother-who regarded women's rights and particularly the right of girls to a good education as the foundation stones of democracy. Naturally the corsage highlights the role of Bryce as Australia's first female governor-general, but it also helps the museum to explain the role of the governor-general more broadly - an important exercise because it is a role that is often misunderstood. It is an object that creates a link between the passions and hopes represented by the suffragettes and today's generation of female leaders who also hold high hopes and dreams for Australian women and girls.

20 Exhibition panel, Accession Number 2011-1851, Museum of Australian Democracy Collection, Canberra.

21 Tim Richards, 'RedPlanet Revisited', The Age, 5 September 2005.

22 Liz McAloon, The Victorian Women's Trust, Email to author, 23 November 2011. 
The material culture of women's political activism is varied, multi-layered and fascinating. By taking inanimate objects and incorporating them in displays that are visually exciting, informative and entertaining, much more than we already know about the lives of Australia's leading women and their leadership styles can be revealed. They allow us to think in different ways about what women's leadership looks like; indeed a feminist perspective of these collections reveals, as Amanda Sinclair states, that there is great diversity in how women live their political lives. It allows us to unpeel the layers that sometimes cloak activism in respectability, revealing hidden strengths and collective activism that have allowed these women to achieve much in improving the lives of all women. Although the MoAD will never be devoted entirely to women's stories, a determined effort should be made to ensure that the stories of women's political activism, whether they were played out in the arena of parliament or more informally elsewhere, are woven into the overall story of Australia's democracy. Women's political activism in Australia was alive long before the first female MPs formally entered the front doors of Old Parliament House. Through the collection and display of items such as those discussed here, and much more, this museum can actively respond to Robyn Archer's appeal to ensure that women's efforts and extraordinary strength are recognised and celebrated.

\section{References}

'Dorothy Tangney, Senator 1943-68.' Australian Women's History Forum. http:// www.womenshistory.com.au/image.asp?iID $=333$.

Eveline, Joan and Lorraine Hayden, eds. Carrying the Banner: Women, Leadership and Activism in Australia. Perth: University of Western Australia Press, 1999.

Examiner [Launceston], 9 November 1998.

Fitzherbert, Margaret. So Many Firsts: Liberal Women from Enid Lyons to the Turnbull Era. Sydney: The Federation Press, 2009.

Herald [Melbourne], 14 June 1975.

Herald Sun, 17 October 2000.

'Make My Day.' Sun Herald, 4 October 1992: 152.

Mercury [Hobart], 29 May 1996.

National Pioneer Women's Hall of Fame, Alice Springs, NT. http://www. pioneerwomen.com.au/index.php. 
National Museum of Australia. Images of Women: Women and Museums in Australia. Canberra: National Museum of Australia, 1994.

National Union of Women's Suffrage Societies. Women's Suffrage in New Zealand \& Australia. London, 1907.

Richards, Tim. 'RedPlanet Revisited.' The Age, 5 September 2005: 14.

The Times, 2 March 1912. 
This text taken from Diversity in Leadership: Australian women, past and present, edited by Joy Damousi, Kim Rubenstein and Mary Tomsic, published 2014 by ANU Press, The Australian National University, Canberra, Australia. 